\title{
Workshop Literasi TIK \& Pengembangan Media Pembelajaran Berbasis TIK untuk Meningkatkan Profesionalisme Guru SD di Kota Parepare
}

\author{
Wawan Krismanto* \\ 1,2Program Studi Pendidikan Guru Sekolah Dasar, Jurusan Ilmu Pendidikan, Fakultas Keguruan dan Ilmu Pendidikan, Universitas Jember
}

\section{A R T I C L E I N F O}

\section{Article history:}

Received 19 Januari 2018

Received in revised form

12 Februari 2018

Accepted 28 Maret 2018

Available online $20 \mathrm{Mei}$

2018

Kata Kunci:

Literasi TIK,

pengembangan media

Keywords:

ICT Literacy, media development

\begin{abstract}
A B S T R A K
Tujuan pengabdian kepada masyarakat ini adalah memberikan pengetahuan dan keterampilan kepada guru-guru sekolah dasar tentang: 1) Literasi TIK, 2) pemanfaatan TIK untuk pembelajaran, dan 3) teknik mengembangkan media pembelajaran berbasis TIK. Untuk membekali kemampuan tersebut, metode yang diterapkan adalah workshop selama 2 hari setara 16 jam pelajaran (JP). Program pengabdian ini telah terlaksana dan diikuti 22 guru dari 7 sekolah dasar negeri di Kota Parepare Sulawesi Selatan. Berdasarkan data evaluasi proses, $64 \%$ peserta menilai sangat baik terhadap pelaksanaan workshop. Kebermanfaatan workshop ini juga dirasakan sangat baik oleh $36 \%$ peserta. Pada unsur materi $82 \%$ peserta menyatakan baik, pada unsur fasilitator $64 \%$ peserta menilai sangat baik serta pada unsur alokasi waktu $50 \%$ peserta beranggapan kurang. Hasil workshop yang tampak diamati yaitu peserta telah mampu: 1) mengeksplorasi pemanfaatan internet untuk menunjang pelaksanaan pembelajaran, seperti youtube, situs pembelajaran, laboratorium virtual, 2) menyusun presentasi yang efektif dan media pembelajaran interaktif menggunakan powerpoint, 3) mengembangkan media pembelajaran berbasis video animasi sederhana memanfaatkan aplikasi animaker dan 4) mengembangkan perangkat evaluasi pembelajaran dengan wondershare quiz creator.
\end{abstract}

\section{A B S T R A C T}

The purpose of community service is to provide knowledge and skills to elementary school teachers about: 1) ICT literation, 2) the use of ICT for learning, and 3) techniques to develop ICTbased learning media. To equip these abilities, the method applied was a 2-day workshop equivalent to 16 hours lesson (JP). This program has been implemented and followed by 22 teachers from 7 public elementary schools in Parepare Town of South Sulawesi. Based on the process evaluation data, $64 \%$ of the participants rated very well for the workshop. The usefulness of this workshop was also felt very well by $36 \%$ of the participants. In the material element $82 \%$ of participants stated good, on the element of facilitator $64 \%$ of participants rated very well and on time allocation element $50 \%$ of participants assume less. The results of the workshops appear to be observed ie the participants have been able to: 1) explore the use of the internet to support the implementation of learning, such as youtube, learning sites, virtual laboratories, 2) to create effective presentations and interactive learning media using powerpoint; 3 ) develop video-based learning media animation simple utilizing animaker application and 4) developing learning evaluation tool with wondershare quiz creator.

\footnotetext{
* Corresponding author.

E-mail addresses: wawan krismanto@gmail.com (Wawan Krismanto)
} 


\section{Pendahuluan}

TIK adalah teknologi yang berhubungan dengan pengambilan, pengumpulan, pengolahan, penyimpanan, penyebaran, dan penyajian informasi. Teknologi Informasi dan Komunikasi (TIK), yang secara sengaja dan kreatif dirancang untuk membantu memecahkan permasalahan pendidikan maupun pembelajaran, kiranya merupakan alternatif yang akan banyak memberikan manfaat dalam upaya peningkatan kualitas pendidikan dan pembelajaran (Andriani, 2015). Seiring dengan perkembangan piranti TIK baik piranti keras (hardware) maupun piranti lunak (software) maka pemanfaatan piranti TIK sebagai media pembelajaran juga semakin berkembang dan beragam. Mulai dari pemanfaatan sederhana berupa LCD sebagai alat bantu memproyeksikan materi pembelajaran sampai pada penyelenggaraan pembelajaran secara virtual (maya) melalui jaringan internet atau electronic learning (e-learning). Bahkan jika dikaitkan dengan fenomena perkembangan gadget seperti handphone, smartphone, tablet dan sejenisnya maka "class without wall" dimana pembelajaran dimana saja, kapan saja dan tentang apa saja menjadi semakin nyata adanya dengan memanfaatkan piranti tersebut. Termasuk pembelajaran di sekolah dasar dimana dewasa ini guru bahkan siswanya telah familiar dengan dunia gadget. Sisa bagaimana seorang guru mampu memanfaatkan berbagai perkembangan TIK tersebut untuk menunjang proses pembelajarannya.

Berbagai studi tentang manfaat dan efektivitas TIK terhadap kualitas proses dan hasil pembelajaran di sekolah dasar telah banyak dilakukan. Pemanfaatan TIK sebagai media pembelajaran di sekolah dasar, secara empiris telah memberi pengaruh positif terhadap motivasi belajar siswa (Halidi dkk.: 2015), minat membaca siswa (Ahmadi:2010), peningkatan aktivitas belajar (Winarni: 2012, Oktaria:2012), sikap ilmiah siswa (Winarni: 2012) dan keterapilan berpikir kritis (Baisa: 2010). Pengaruh positif pemanfaatan TIK dalam proses pembelajaran kemudian mendorong pada peningkatan hasil belajar siswa di sekolah dasar dalam beberapa mata pelajaran, seperti yang dijelaskan dalam berbagai hasil penelitian (Halidi dkk.: 2015, Winarni: 2012, Baisa: 2010, dan Oktaria: 2012). Syarifuddi (2014) menyatakan bahwa fenomena perkembangan TIK memang telah merambah ke seluruh pelosok kehidupan masyarakat dalam waktu cepat. Sehingga apa yang disampaikan Morgan Stanley bahwa penetrasi internet di masyarakat termasuk yang paling cepat dibandingkan media teknologi komunikasi dan informasi lainnya seperti radio dan televisi benar adanya.

Berdasarkan berbagai studi penelitian terdahulu tersebut maka menjadi penting bagi guru untuk memiliki kemampuan yang cukup dalam literasi TIK. Literasi dalam hal ini tidak hanya sekedar memiliki piranti lalu mampu mengakses (membaca) informasi dari piranti TIK. Namun literasi diartikan sebagai kemampuan untuk membaca (dengan komprehensif) serta menulis (menciptakan, mendesain, maupun memproduksi). Dengan demikian dapat dikatakan bahwa literasi bergerak dari sekedar mengenali (recognize) dan membandingkan (comprehending) informasi ke tingkat yang lebih tinggi yakni kemampuan berpikir kritis secara implisit dalam mempertanyakan, menganalisa, mengevaluasi informasi tersebut kemudian mendesain, menciptakan dan membuat informasi baru dalam bentuk atau format yang berbeda (Tanti: 2012). Dalam hal ini ETS (2006) mendefinisikan literasi TIK sebagai kemampuan untuk menggunakan teknologi digital, alat komunikasi dan jaringan tepat untuk memecahkan masalah informasi dalam rangka untuk berfungsi dalam masyarakat informasi. Secara spesifik Ali dan Katz (2010) menyebutkan tujuh elemen literasi TIK yaitu : define, access, evaluate, manage, integrate, create, dan communicate. Dengan demikian tuntutan akan kemampuan literasi TIK oleh para guru menjadi semakin relevan di era sekarang ini, apalagi dikaitkan dengan profil guru profesional. Menurut Masyhur (206) beberapa model pengembangan literasi menjadi rujukan dalam menyusun formulasi model pengembangan literasi TIK. Model ini dikembangkan berdasarkan elemen literasi TIK yang didefinisikan oleh ETS yaitu access, manage, integrate, evaluate, dan create. Kemudian model tersebut merupakan hasil modifikasi dengan penambahan beberapa penekanan, seperti faktor ketertarikan informasi pengguna TIK serta media yang paling 'nyaman' digunakan oleh pengguna. Faktor-faktor tersebut diyakini dapat mempercepat proses pengembangan literasi TIK. Siswanto (2012) yang menjelaskan bahwa literasi komputer masyarakat pedesaan cenderung memiliki kemampuan yang sifatnya mandiri. Artinya mereka yang memiliki literasi TIK tinggi disebabkan proses pembelajaran mandiri atau pernah mengikuti pendidikan baik formal maupun informal. Menurut Street (1984) dalam (Tibor, 2011), definisi literasi yang paling banyak digunakan adalah literasi sebagai praktek sosial dimana didalamnya terdapat konsep kemampuan membaca dan menulis

Guru professional termasuk guru di sekolah dasar adalah ujung tombak pelaksanaan pembelajaran di kelas yang kini dituntut untuk mampu menggunakan dan memanfaatkan perkembangan teknologi informasi dan komunikasi untuk menunjang proses pembelajarannya. Terkait dengan hal ini, Permendiknas No.16/2007 tentang Standar Kualifikasi Akademik \& Kompetensi Guru menegaskan bahwa Standar Kompetensi Guru Kelas SD/MI, Guru Mata Pelajaran di SD/MI, SMP/MTs, SMA/MA, dan 
SMK/MAK diantaranya adalah 1) Memanfaatkan teknologi informasi dan komunikasi untuk kepentingan pembelajara (Kompetensi Pedagogik No.5) dan 2) Memanfaatkan teknologi informasi dan komunikasi untuk berkomunikasi dan mengembangkan diri (Kompetensi Profesional No.24). Dengan demikian apapun kondisinya, berprofesi menjadi guru, apalagi menjadi professional, mampu menggunakan dan memanfaatkan teknologi informasi dan komunikasi sebagai penunjang proses pembelajaran menjadi sangat penting dan strategis. Mustofa (2007) berpendapat bahwa proses menuju guru profesional ini perlu didukung oleh semua unsur yang terkait dengan guru. Unsur-unsur tersebut dapat dipadukan untuk menghasilkan suatu sistem yang dapat dengan sendirinya bekerja menuju pembentukan guru-guru yang profesional dalam kualitas maupun kuantitas yang mencukupi.

Seperti yang telah diuraikan di atas bahwa media pembelajaran merupakan komponen pembelajaran yang semakin berkembang sebagai efek dari perkembangan teknologi informasi dan komunikasi. Berdasarkan kajian teori dan hasil berbagai penelitian maka dapat disimpulkan bahwa media pembelajaran berbasis TIK memberi dampak positif bagi proses dan hasil, yaitu: 1) mampu mengatasi berbagai hambatan seperti verbalisme, salah tafsir, tidak ada fokus perhatian, bosan/jenuh, 2) mampu memberikan beberapa kelebihan seperti fiksatif, manipulatif dan distributif, 3) mampu bangkitkan motivasi dan emosi, 4) mampu mengorganisasikan informasi secara terstandar dan sistematis, 5) mampu mengatasi keterbatasan ruang, waktu dan daya indera, 6) melalui fasilitas multimedia dan interaktif, mampu menjembatani kepasifan belajar dan memaksimalkan potensi hasil belajar.

Namun demikian, terdapat permasalahan pada sebagian besar guru yaitu pemahaman TIK (literasi TIK) yang masih rendah meskipun fasilitas dan akses pada TIK semakin mudah dijangkau. Misalkan saja begitu banyak guru yang telah memiliki laptop, smartphone dan jaringan internet, namun berapa banyak yang sudah memanfaatkannya untuk kepentingan pembelajaran? Untuk itu mutlak diperlukan guru-guru yang melek dengan TIK khususnya media informasi. Hal ini sering diistilahkan dengan literasi TIK. Literasi TIK tidak hanya sekedar mengetahui dan mampu mengakses berbagai piranti TIK. Namun jauh dari itu adalah kemampuan guru untuk mendapatkan manfaat sesuai kebutuhan bagi dirinya serta kemampuan untuk menciptakan produk baru berdasarkan krativitas lalu disebarluaskan untuk orang lain, minimal untuk siswanya sendiri.

Melihat dari sisi kebermanfaatan pemahaman tentang literasi TIK dan pengembangan media pembelajaran berbasis TIK tersebut, maka mendesak bagi guru untuk diberikan bekal pemahaman dan keterampilan tentang literasi TIK dan pengembangan media pembelajaran berbasis TIK. Untuk itu, berdasarkan survei sederhana, pengamatan dan pengalaman mengajar TIK di program studi lanjut, dapat disimpulkan bahwa kemampuan tentang TIK guru-guru sekolah dasar di Kota Parepare masih belum merata dan masih bisa dikategorikan rendah. Pemahaman literasi TIK juga masih awam sehingga fasilitas teknologi informasi dan komunikasi yang sebenarnya mereka telah miliki belum mampu dimanfaatkan secara maksimal untuk menunjang proses pembelajarannya. Selain terkait dengan pendidikan, mereka juga terkendala dengan faktor usia, sarana dan prasarana, motivasi serta kesempatan mendapatkan workshop TIK yang sangat terbatas. Seiring dengan hal tersebut maka program pengabdian kepada masyarakat ini fokus pada permasalahan yang di hadapi mitra sebagai berikut: 1) Pemahaman mitra tentang konsep Literasi TIK yang rendah. 2) Pemahaman mitra dalam memanfaatkan TIK untuk mengembangkan media pembelajaran pada pembelajaran mereka di sekolah dasar masih rendah. Dan 3) Kemampuan mitra dalam hal teknik mengembangkan media pembelajaran berbasis TIK masing sangat terbatas. Seiring dengan hal tersebut maka program pengabdian kepada masyarakat ini fokus pada permasalahan yang di hadapi mitra atau guru sasaran yaitu: 1) Pemahaman mitra tentang konsep literasi TIK yang rendah. 2) Pemahaman mitra dalam memanfaatkan TIK untuk mengembangkan media pembelajaran yang masih rendah pula, dan 3) Kemampuan mitra dalam hal teknik mengembangkan media pembelajaran berbasis TIK yang juga sangat terbatas. Permasalahan-permasalahan tersebut disimpulkan berdasarkan pengamatan yang disertai dengan diskusi di lima Kelompok Kerja Guru (KKG) di wilayah Kota Parepare pada saat studi pendahuluan sebelum program pengabdian ini dilaksanakan. Dengan demikian solusi dari tim pelaksana pengabdian berupa workshop literasi TIK \& pengembangan media pembelajaran berbasis TIK bagi guru Sekolah Dasar kiranya tepat untuk diberikan kepada mitra atau guru sasaran.

Berbagai studi terdahulu tentang manfaat dan efektivitas TIK terhadap kualitas proses dan hasil pembelajaran di sekolah dasar telah banyak dilakukan. Pemanfaatan TIK sebagai media pembelajaran di sekolah dasar, secara empiris telah memberi pengaruh positif terhadap motivasi belajar siswa (Halidi dkk.: 2015), minat membaca siswa (Ahmadi:2010), peningkatan aktivitas belajar (Winarni: 2012, Oktaria:2012), sikap ilmiah siswa (Winarni: 2012) dan keterapilan berpikir kritis (Baisa: 2010). Pengaruh positif pemanfaatan TIK dalam proses pembelajaran kemudian mendorong pada peningkatan hasil belajar siswa di sekolah dasar dalam beberapa mata pelajaran, seperti yang dijelaskan dalam berbagai hasil penelitian (Halidi dkk.: 2015, Winarni: 2012, Baisa: 2010, dan Oktaria: 2012). 
Berdasarkan berbagai studi penelitian terdahulu tersebut maka menjadi penting bagi guru untuk memiliki kemampuan yang cukup dalam literasi TIK. Literasi dalam hal ini tidak hanya sekedar memiliki piranti lalu mampu mengakses (membaca) informasi dari piranti TIK. Namun literasi diartikan sebagai kemampuan untuk membaca (dengan komprehensif) serta menulis (menciptakan, mendesain, maupun memproduksi). Dengan demikian dapat dikatakan bahwa literasi bergerak dari sekedar mengenali (recognize) dan membandingkan (comprehending) informasi ke tingkat yang lebih tinggi yakni kemampuan berpikir kritis secara implisit dalam mempertanyakan, menganalisa, mengevaluasi informasi tersebut kemudian mendesain, menciptakan dan membuat informasi baru dalam bentuk atau format yang berbeda (Tanti: 2012). Dalam hal ini ETS (2006) mendefinisikan literasi TIK sebagai kemampuan untuk menggunakan teknologi digital, alat komunikasi dan jaringan tepat untuk memecahkan masalah informasi dalam rangka untuk berfungsi dalam masyarakat informasi. Secara spesifik Ali dan Katz (2010) menyebutkan tujuh elemen literasi TIK yaitu : define, access, evaluate, manage, integrate, create, dan communicate. Dengan demikian tuntutan akan kemampuan literasi TIK oleh para guru menjadi semakin relevan di era sekarang ini, apalagi dikaitkan dengan profil guru profesional.

\section{Metode}

Untuk menjawab permasalahan yang telah diuraikan pada bab sebelumnya, maka pengabdian kepada masyarakat ini menawarkan solusi berupa "Workshop Literasi TIK \& Pengembangan Media Pembelajaran Berbasis TIK Bagi Guru Sekolah Dasar". Jadi dalam kegiatan ini mitra kegiatan, diberikan bekal kemampuan berupa: 1) Pengetahuan dan pemahaman tentang konsep Literasi TIK, 2) Pengetahuan dan pemahaman tentang pemanfaatan TIK untuk mengembangkan media pembelajaran pada pembelajaran mereka di sekolah dasar, dan 3) Pengetahuan dan keterampilan tentang teknik mengembangkan media pembelajaran berbasis TIK.

Guna memberikan bekal kemampuan di atas, maka metode pendekatan yang diterapkan dalam kegiatan ini adalah workshop yang didalamnya terdiri dari penyampaian materi tentang konsep literasi TIK, konsep TIK untuk pembelajaran di Sekolah Dasar dan praktikum tentang teknik mengembangkan media pembelajaran berbasis TIK dalam hal ini berbasis internet, video, animasi sederhana dan powerpoint. Materi-materi tersebut diberikan dalam dua kali pertemuan. Setiap pertemuan terdiri dari empat sesi dan masing-masing sesi berlangsung selama 100 menit. Dengan demikian pelaksanaan pengabdian ini berlangsung selama $16 \mathrm{JP}$. Materi workshop dalam kegiatan pengabdian ini terdiri dari materi yang mengandung unsur pengetahuan (kognitif) dan unsur keterampilan (psikomotorik), oleh karena itu metode yang diterapkan dalam workshop berupa ceramah dan metode demonstrasi (praktikum) dengan proporsi masing-masing 20\% dan 80\%. Selain itu, dikarenakan mitra/sasaran terdiri dari para guru yang telah memiliki pengalaman mengajar yang cukup lama, maka proses pembelajaran dalam workshop ini menggunakan metode pembelajaran orang dewasa. Memanfaatkan pengalaman yang telah mereka miliki sebelumnya sangat mendominasi dan sifatnya sharing pengetahuan dan keterampilan. Dalam proses pembelajaran, instruktur menggali pengetahuan dan pengalaman mitra/sasaran baik pada saat menjelaskan materi maupun pada saat mempraktekkan pengembangan media pembelajaran berbasis TIK. Dengan demikian selama berlangsungnya proses pembelajaran dalam workshop ini berjalan secara interaktif. Pada setiap sesi pembelajaran diawali dengan memberikan pemahaman tentang konsep lalu dilanjutkan dengan praktek langsung oleh peserta yang dibimbing langsung oleh instruktur. Dengan metode ini peserta akan lebih memahami materi karena konsep langsung dipraktekkan.

\section{Hasil dan pembahasan}

\section{Hasil}

Program pengabdian berupa workshop literasi TIK \& pengembangan media pembelajaran berbasis TIK bagi guru Sekolah Dasar di Kota Parepare telah terlaksana dengan tahapan yang dapat dijelaskan berikut ini.

1. Tahap persiapan, tahapan ini meliputi:

a. Observasi lokasi. Dengan mempertimbangkan efisiensi dan efektivitas pelaksanaan kegiatan maka tim secara langsung menentukan dan mengobservasi kesiapan lokasi pelaksanaan kegiatan yakni di ruang laboratorium TIK UPP PGSD Parepare Kampus V UNM di Jl. Sudirman No. 56 Kota Parepare.

b. Mengurus surat ijin. Setelah kegiatan observasi, tim akan mengurus surat ijin kepada Kepala UPP PGSD Parepare agar diberikan ijin menggunakan fasilitas ruang laboratorium TIK untuk pelaksanaan kegiatan pengabdian masyarakat ini.

c. Menentukan jadwal pelaksanaan kegiatan. 


\section{Tahap Pelaksanaan}

Pelaksanaan kegiatan pengabdian kepada masyarakat melalui program "Workshop Literasi TIK \& Pengembangan Media Pembelajaran Berbasis TIK Bagi Guru Sekolah Dasar" kepada mitra (dalam hal ini guru sekolah dasar di Kota Parepare) telah dilaksanakan dengan jadwal pelaksanaan sebagai berikut:

Tabel 1. Jadwal Pelaksanaan Kegiatan Pengabdian

\begin{tabular}{ccl}
\hline HARI & SESI & \multicolumn{1}{c}{ MATERI } \\
\hline Pertama & I & $\begin{array}{l}\text { 1. Pembukaan } \\
\text { 2. Literasi TIK \& Media Informasi }\end{array}$ \\
\cline { 2 - 3 } & II & 3. Internet Untuk Menunjang Pembelajaran Di SD \\
\cline { 2 - 3 } & III & 4. Lanjutan Internet Untuk Menunjang Pembelajaran Di SD \\
\cline { 2 - 3 } IV & 5. Tenik Menyusun Media Pembelajaran Dengan Powerpoint \\
\hline Kedua & I & $\begin{array}{l}\text { 6. Mengembangkan Media Pembelajaran Berbasis Video dan Animasi } \\
\text { Dengan Aplikasi Animaker }\end{array}$ \\
\cline { 2 - 3 } & II & $\begin{array}{l}\text { 7. Praktikum Mengembangkan Media Pembelajaran Berbasis Video dan } \\
\text { Animasi Dengan Aplikasi Animaker }\end{array}$ \\
\cline { 2 - 3 } & III & 8. Evaluasi Pembelajaran Dengan Wondershare Quiz Creator \\
\cline { 2 - 3 } & IV & $\begin{array}{l}\text { 9. Praktikum Menyusun Evaluasi Pembelajaran Dengan Wondershare Quiz } \\
\text { Creator }\end{array}$ \\
\hline
\end{tabular}

Sesuai yang telah diuraikan di atas bahwa antusias yang ditunjukkan peserta untuk mempelajari materi-materi yang diberikan pada workshop ini mendorong pada keberhasilan pelaksanaan workshop ini. Sesuai dengan target luaran kegiatan ini yaitu: 1) peningkatan pengetahuan dan pemahaman mitra yaitu guru-guru sekolah dasar tentang konsep Literasi TIK, 2) Peningkatan pengetahuan dan pemahaman mitra yaitu guru-guru sekolah dasar tentang pemanfaatan TIK untuk mengembangkan media pembelajaran pada pembelajaran mereka di sekolah dasar dan 3) Peningkatan pengetahuan dan keterampilan mitra yaitu guru-guru sekolah dasar tentang teknik mengembangkan media pembelajaran berbasis TIK, maka pelaksanaan dilapangan menunjukkan semua target luaran dapat tercapai meskipun masih ada kekurangannya. Indikator dari keberhasilan ini dapat dilihat dari hasil evaluasi proses dan hasil yang dicapai oleh peserta. Evaluasi proses dilakukan dengan memberikan angket/kuesioner kepada peserta yang berisi tentang pernyataan seputar pelaksanaan workshop. Evaluasi hasil dilakukan dengan mengamati perubahan pemahaman dan keterampilan. Berikut beberapa dokumentasi pelaksanaan kegiatan pengabdian ini.

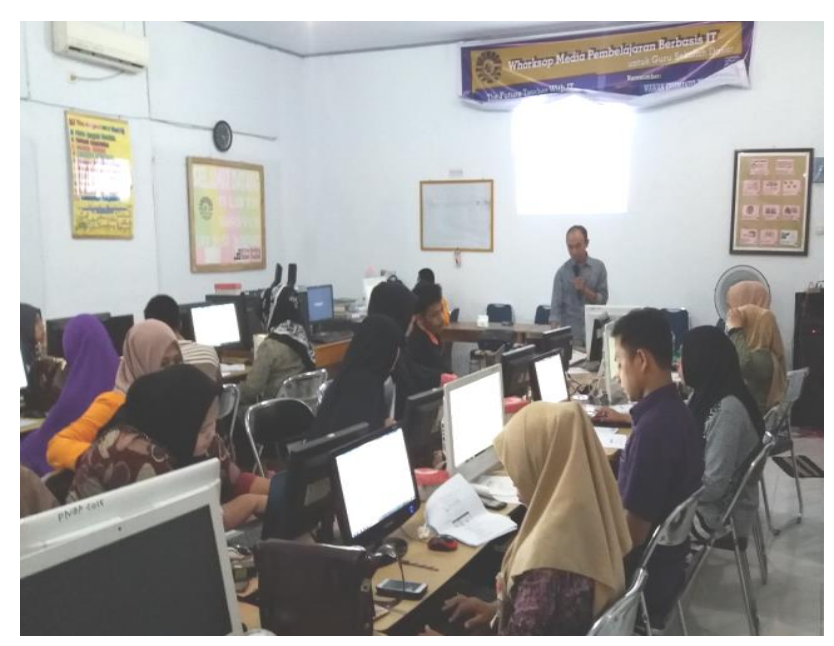

Gambar 1. Fasilitator menyampaikan materi tentang media pembelajaran berbasis video dan animasi sederhana serta evaluasi pembelajaran dengan quiz creator 


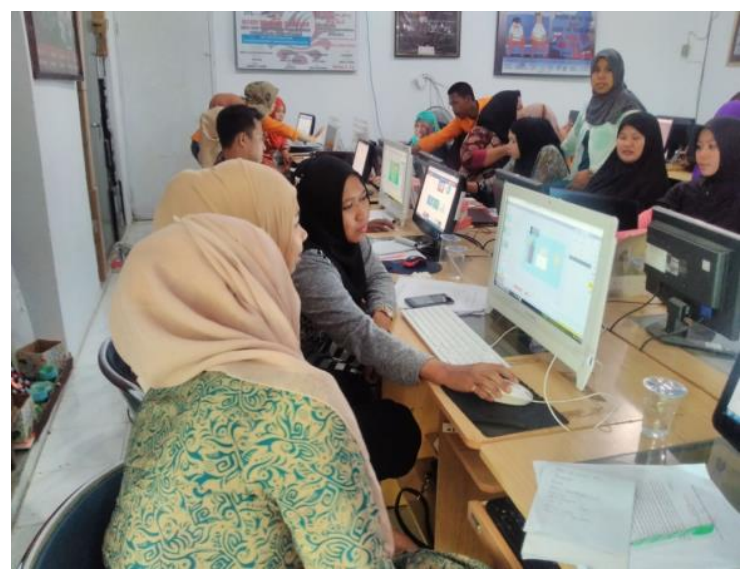

Gambar 2. Para peserta antusias mengikuti jalannya workshop yang langsung praktek dengan bimbingan fasilitator dibantu beberapa mahasiswa.

Berdasarkan data evaluasi proses, $64 \%$ peserta menilai Sangat Baik terhadap pelaksanaan workshop pada kegiatan pengabdian kali ini. Selain itu kebermanfaatan workshop ini dirasakan Sangat Baik oleh 36\% peserta dan Baik oleh 55\% peserta. Pada unsur materi $82 \%$ menyatakan Baik dan pada unsur fasilitator, 64\% peserta menilai Sangat Baik. Sementara itu, pada unsur alokasi waktu 50\% peserta beranggapan kurang. Berikut tabel rangkuman data hasil evaluasi proses tersebut.

Tabel 2. Rekap Hasil Evaluasi Proses Workshop

\begin{tabular}{lcccc}
\hline \multicolumn{1}{c}{ Unsur yang dievaluasi } & $\begin{array}{c}\text { Sangat } \\
\text { Baik }\end{array}$ & Baik & Cukup & Kurang \\
Pelaksanaan workshop secara keseluruhan & $14 \%$ & $64 \%$ & $22 \%$ & $0 \%$ \\
Kebermanfaatan workshop untuk menunjang kinerja & $36 \%$ & $55 \%$ & $9 \%$ & $0 \%$ \\
guru & $18 \%$ & $82 \%$ & $0 \%$ & $0 \%$ \\
Kualitas materi yang diajarkan (termasuk handout) & $64 \%$ & $27 \%$ & $9 \%$ & $0 \%$ \\
Kemampuan fasilitator dalam menjelaskan materi & $9 \%$ & $32 \%$ & $9 \%$ & $50 \%$ \\
\hline Alokasi waktu yang disediakan & &
\end{tabular}

Meskipun hasil atau karya yang dihasilkan oleh para peserta tidak dinilai tersendiri secara khusus, namun hasil workshop yang tampak dan dapat diamati adalah para peserta telah mampu: a) Memanfaatkan perangkat komputer dan internet untuk mengakses kontens kontens pembelajaran yang dapat dimanfaatkan untuk pembelajaran mereka di sekolah dasar, b) Mengeksplorasi pemanfaatan internet untuk menunjang pelaksanaan pembelajaran mereka di sekolah seperti memanfaatkan google, google scholar, e-library dan e-journal, c) searching video melalui youtube kemudian mengunduhnya untuk kepentingan proses pembelajarannya, d) Memanfaatkan situs-situs pembelajaran dan mengeksplor fasilitas yang ada di dalamnya seperti Path, Rumah Belajar Kemendikbud dll., e) Menyusun presentasi yang efektif dengan menggunakan powerpoint baik untuk presentasi maupun keperluan mengajar, f) Menyusun media pembelajaran yang interaktif dengan memanfaatkan kemampuan powerpoint yang telah mereka memiliki, g) Mengembangkan media pembelajaran berbasis video dan animasi sederhana dengan memanfaatkan aplikasi animaker, dan h) Mengembangkan perangkat evaluasi pembelajaran dengan memanfaatkan wondershare quiz creator.

\section{Pembahasan}

Secara keseluruhan pelaksanaan pengabdian ini telah berjalan dengan lancar. Secara proses, kegiatan pengabdian ini telah dianggap berjalan dengan baik oleh para peserta kegiatan. Secara hasil, kegiatan pengabdian ini telah menunjukkan perubahan baik dari sisi pemahaman maupun keterampilan para mitra dalam hal ini guru sasaran. Hal ini ditandai dengan: 1) peningkatan pengetahuan dan pemahaman mitra yaitu guru-guru sekolah dasar tentang konsep Literasi TIK, 2) peningkatan pengetahuan dan pemahaman mitra yaitu guru-guru sekolah dasar tentang pemanfaatan TIK untuk mengembangkan media pembelajaran pada pembelajaran mereka di sekolah dasar dan 3) peningkatan pengetahuan dan keterampilan mitra yaitu guru-guru sekolah dasar tentang teknik mengembangkan media pembelajaran berbasis TIK. Dengan demikian permasalahan-permasalah yang ada pada mitra atau 
guru sasaran telah terfasilitasi oleh kegiatan pengabdian ini, meskipun masih ada beberapa kelemahan atau kekurangan misal dari sisi alokasi waktu yang masih dianggap terlalu singkat sehingga dianggap kurang dalam hal pendalaman materi yang dipelajari peserta selama workshop.

Faktor pendorong keberhasilan pelaksanaan pengabdian berupa workshop media pembelajaran berbasis TIK bagi Guru SD kali ini adalah: 1) Waktu pelaksanaan yang bersamaan dengan libur semester membuat peserta tidak terikat dengan tugas dan kewajiban mengajar sehingga peserta lebih fokus mengikuti kegiatan secara penuh dari awal sampai akhir kegiatan, 2) Motivasi yang sangat baik dari peserta dalam mengikuti seluruh rangkaian kegiatan, 3) Fasilitas yang cukup memadai dalam hal perangkat komputer dan jaringan internet yang tersedia di laboratorium komputer Kampus V UNM, 4) Instruktur yang kompeten dan berpengalaman dalam bidangnya, 5) Sebagian besar peserta telah memiliki pengetahuan dan skill tentang dasar-dasar komputer dan software dengan cukup baik. Keberhasilan pelaksanaan pengabdian ini membawa harapan bahwa peserta akan menerapkan pengetahuan dan keterampilan yang didapatkan guna meningkatkan kualitas pembelajarannya. Penerapan yang dijalankan secara konsisten dan kontinyu pada akhirnya akan mendorong pada terwujudnya profesionalisme para guru SD yang menjadi peserta pengabdian ini. Adapun yang menjadi faktor penghambat dalam pelaksanaan pengabdian kali ini adalah: 1) Sumber daya listrik di lokasi pelaksanaan pengabdian kurang stabil sehingga sempat beberapa kali menghambat jalannya kegiatan, 2) Beberapa perangkat laptop yang dibawa sendiri oleh peserta belum terinstal software-software yang digunakan selama workshop sehingga cukup menyita waktu dalam proses pembelajaran.

Namun demikian secara keseluruhan "Workshop Literasi TIK \& Pengembangan Media Pembelajaran Berbasis TIK Bagi Guru Sekolah Dasar" telah membekali guru-guru peserta workshop dengan pemahaman konsep literasi TIK. Perubahan pemahaman ini tentu membawa sebuah harapan kedepannya bahwa mereka akan menjadi guru profesional yang tidak hanya memiliki akses dan mampu mengakses perangkat TIK yang dimiliki. Namun hal yang penting juga adalah perangkat TIK yang dimilikinya tersebut mampu dimanfaatkan semaksimal mungkin untuk menunjang proses pembelajarannya, bahkan diharapkan akan menjadi sarana mereka melakukan berbagai inovasi pembelajarannya. Merujuk pada konsep yang diuraikan ETS (2006), literasi TIK merupakan kemampuan untuk menggunakan teknologi digital, alat komunikasi dan jaringan untuk memecahkan masalah informasi, maka tambahan kompetensi guru dalam hal literasi TIK yang didapatkan melalui kegiatan pengabdian ini akan menjadi dasar mereka dalam memecahkan masalah pembelajaran masa kini yang mereka hadapi. Sebagai contoh adalah bagaimana menghadapi peserta didik masa kini yang dikenal sebagai generasi digital native yaitu peserta didik yang sangat familiar dengan dunia digital dan berbagai piranti TIK. Kemampuan para guru sasaran dalam hal literasi TIK akan mendorong mereka menyesuaikan dengan pola dan gaya belajar generasi digital native. Prensky (2001) mengungkapkan bahwa para pendidik di masa kini harus dapat menyesuaikan materi belajar yang mereka sampaikan dengan "the language of Digital Natives". Kemampuan guru memanfaatkan TIK untuk kepentingan pembelajarannya akan membuat peserta didiknya merasa mudah mengikuti bahkan senang atau termotivasi lantaran dengan "bahasa" yang sama. Materi-materi ajar yang biasanya diberikan dengan verbalisme, kini disampaikan dengan sumber belajar dan media belajar yang beragam dalam bentuk video, animasi dan multimeda yang semuanya itu menjadi media yang sangat familiar bagi peserta didiknya saat ini.

Selanjutnya, perubahan pemahaman dan keterampilan guru peserta workshop mendorong para guru memanfaatkan piranti TIK yang dimiliknya secara maksimal tidak hanya mengakses informasi, namun juga untuk mengelola informasi, mengintegrasikan berbagai informasi bahkan berkreasi lalu berbagi informasi. Dengan demikian secara langsung hasil kegiatan pengabdian ini mendorong para peserta (guru sasaran) meningkatkan kemampuannya dalam hal literasi TIK. Secara spesifik Ali dan Katz (2010) menyebutkan tujuh elemen literasi TIK yaitu : define, access, evaluate, manage, integrate, create, dan communicate. Sebagai contoh sederhana adalah kini peserta workshop (guru sasaran) mampu mencari dan mengunduh berbagai sumber referensi dari internet, berbagai media pembelajaran dari situs-situs pembelajaran dan youtube, setelah itu berbagai informasi yang didapatnya tersebut diintegrasikan dalam sebuah media pembelajaran sederhana berbasis powerpoint lalu berbagai dengan orang lain minimal disampaikan kepada siswanya. Hal ini mereka lakukan baik memanfaatkan laptop,pc maupun smartphone yang mereka miliki.

Berdasar pada uraian di atas maka sebagai rekomendasi hasil kegiatan pengabdian ini adalah perlu upaya intensif dari berbagai kalangan pendidikan salah satunya adalah lembaga pendidik dan tenaga kependidikan (LPTK) untuk lebih giat melakukan kegiatan pengabdian serupa. Sebagian guru memang telah memiliki kompetensi TIK yang tinggi dan memiliki kemampuan literasi TIK yang tinggi pula, namun sebagian lagi tidaklah demikian. TIK memang bukan segala-galanya untuk meningkatkan kualitas pembelajaran. Namun berbagai studi yang telah diuraikan di atas menunjukkan bahwa pemanfaatan TIK dalam pembelajaran mampu mendorong pada perbaikan kualitas proses pembelajaran 
dan ujungnya mampu mendorong peningkatan hasil pembelajaran. Untuk itu perlu dukungan berbagai pihak untuk meningkatkan literasi TIK para guru sehingga akan mendorong mereka untuk mau dan mampu memanfaatkan piranti TIK yang dimilikinya secara maksimal untuk menunjang proses pembelajarannya.

\section{Simpulan dan saran}

Pelaksanaan pengabdian kepada masyarakat berupa “Workshop Literasi TIK \& Pengembangan Media Pembelajaran Berbasis TIK Bagi Guru Sekolah Dasar" yang dilaksanakan selama dua hari telah berjalan dengan baik dan lancar. Materi yang diberikan oleh fasilitator dapat diaplikasikan peserta workshop. Pemahaman mitra tentang konsep Literasi TIK dan Informasi cukup menggembirakan sehingga optimis dalam kesehariannya mereka dapat memanfaatkan perangkat TIK yang dimilikinya untuk mengakses, memilah dan menggunakannya untuk menunjang proses pembelajaran di kelasnya masing-masing. Dengan demikian diharapkan dengan pemahaman yang baik tentang Literasi TIK akan memberi efek positif bagi siswa-siswinya, terutama terkait dengan motivasi belajar, hasil belajar dan perilaku pemanfaatan TIK untuk hal yang positif. Hasil evaluasi baik evaluasi proses maupun evaluasi hasil workshop menunjukkan hasil yang memuaskan. Guru SD sebagai mitra pengabdian cukup merasakan manfaatnya, kompetensi dalam bidang TIK khususnya bagaimana memanfaatkannya untuk menunjang proses pembelajaran dapat meningkat. Hal ini akan bermanfaat bagi mereka secara praktis dalam melaksanakan pembelajaran di kelas masing-masing. Mereka punya alternatif dalam menyampaikan pembelajarannya yakni pembelajaran berbasis teknologi informasi dan komunikasi yang mereka dapatkan dari kegiatan pengabdian kali ini.

Saran yang dapat diberikan berdasarkan pelaksanaan kegiatan pengabdian ini adalah perlu penambahan waktu pelaksanaan sehingga peserta dapat benar-benar menunjukkan kemampuannya dalam mengembangkan media pembelajaran dan perangkat evaluasi secara utuh. Selain itu mereka ada kesempatan untuk menunjukkan hasil karyanya dan saling berbagi dengan sesama peserta dalam hal tehnik pembuatannya maupun hasil karyanya itu sendiri, sehingga dapat dimanfaatkan pada pembelajaran di sekolah dasar.

\section{Daftar Rujukan}

Ali, R., \& Katz, I. R. (2010). Information and Communication Technology Literacy: What Do Businesses Expect and What Do Business Schools Teach? Princeton: Educational Testing Service.

Ahmadi, Farid. (2010). Meningkatkan Minat Membaca Siswa Sekolah Dasar Dengan Metode Glenn Doman Berbasis Multimedia. Jurnal Penelitian Pendidikan Volume 27 Nomor 1 Tahun 2010 halaman 64-71.

Andriani, Tuti. 2015. Sistem Pembelajaran Berbasis Teknologi Informasi Dan Komunikasi Sosial Budaya: Media Komunikasi Ilmu- Ilmu Sosial dan Budaya, Volume 12 Nomor 1.

Baisa, Idi Rathomy. (2010). Pengaruh penerapan media pembelajaran berbasis web terhadap keterampilan berpikir kritis dan kemampuan konitif siswa Kelas V SD Islam Sabilillah Malang. Tesis. Pendidikan Dasar, Universitas Negeri Malang. Diakses di http://karyailmiah.um.ac.id./index.php/\%20disertasi/article/view/5763. (diakses 24 September 2017)

ETS. (2006). ICT Literacy Assessment Preliminary Findings. http://www.ets.org/Media/Products/ICT_Literacy/pdf/2006_Preliminary_Findings. pdf.

Halidi, Hasan Mahmud. Sarjan N. Husain dan Sahrul Saehana. (2015). Pengaruh Media Pembelajaran Berbasis TIK Terhadap Motivasi Dan Hasil Belajar IPA Siswa Kelas V SDN Model Terpadu Madani Palu. e-Jurnal Mitra Sains, Volume 3 Nomor 1, Januari 2015 hlm 53-60.

Masyhur, Firdaus. 2016. "Model Pengembangan Literasi TIK Masyarakat Tani dan Nelayan The ICT Literacy Development Model for Farmers and Fishermen Community". Balai Besar Pengkajian dan Pengembangan Komunikasi dan Informatika Makassar Jurnal Pekommas, Vol. 1 No. 1, April 2016: $101-110101$

Mustofa. 2007. Upaya Pengembangan Profesionalisme Guru di Indonesia. Jurnal Ekonomi \& Pendidikan, Volume 4 Nomor 1, April 2007 Staf Pengajar FISE Universitas Negeri Yogyakarta. 
Oktaria, Ike. (2012). Pemanfaatan media pembelajaran berbasis mirosoft powerpoint untuk meningkatkan aktivitas dan hasil belajar PKn siswa kelas III SDN Cemorokandang 2 Malang. Skripsi. Program Studi PGSD, Universitas Negeri Malang. Diakses di http://library.um.ac.id/ptk/index.php?mod=detail\&id=55985. (diakses 17 September 2017)

Saleh, Baso. 2015. Literasi Teknologi Informasi dan Komunikasi (TIK) Masyarakat di Kawasan Mamminasata. Balai Besar Pengkajian dan Pengembangan Komunikasi dan Informatika Jurnal Pekommas, Vol. 18 No. 3, Desember 2015: 151 - 160

Sharma, A. K. (2014). Information Needs of the Farmers in Madhya Pradesh : A Study, 4(2), 135-140.

Siswanto, S. (2012). Literasi Teknologi Informasi dan Komunikasi (TIK) Masyarakat Desa Pantai. Jurnal Studi Komunikasi Dan Media, 16(2), 81-110.

Syarifuddin. 2014. Literasi Teknologi Informasi dan Komunikasi. Balai Besar Pengkajian Dan Pengembangan Komunikasi Dan Informatika (BBPPKI) Jurnal Penelitian Komunikasi Vol. 17 No.2, Desember 2014: 153-164

Tibor, K. (2011). The Media and The Literacies: Media Literacy, Information Literacy, Digital Literacy, 33(2), 211-221.

Tanti, Dewi S. (2012). Strategi Literasi Media Baru: Selancar di tengah Dinamika Teknologi dan Kondisi Sosial Politik (makalah Dipresentasikan dalam Call For Paper UMS, 2012)

Winarni, Endang Widi. (2012). Penggunaan Value Clarification Dengan Media Computer Assisted Instruction (CAI) Untuk Peningkatan Aktivitas Pembelajaran Ilmu Pengetahuan Alam (IPA), Sikap Ilmiah, Dan Hasil Belajar Siswa Sekolah Dasar (SD). Jurnal Exacta, Vol. X. No. 2 Desember 2012 halaman 106-110 